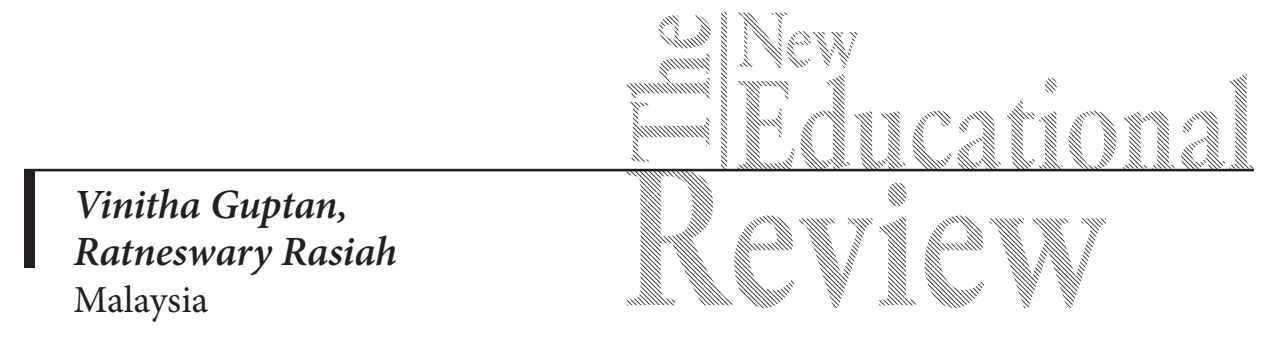

\title{
Competence Development in Business Undergraduates: The Role of Formative Assessment and Humour
}

DOI: 10.15804/tner.2016.45.3.13

\begin{abstract}
This study examined the perceived impact of formative assessment and humour on the learning experience and the development of graduate attributes of business undergraduate students. Data from 236 valid respondents of a questionnaire was analyzed using Partial Least Squares-Structural Equation Modeling method. The conceptual framework for this study is based on Dewey's theory of reflective thought and action and Ziv's theory of the attention-gaining and holding power of humour. Findings indicate positive and significant roles played by formative assessment and humour in enhancing learning experience and student development. It was found that applied academic writing and poster presentations were student-centered learning methods that had a positive impact on learning experience and successfully supported differentiated learners. Humour was found to add value to students' overall learning experience. The findings of this study will provide higher education institutions with a set of considerations for devising formative assessment strategies and practices that will successfully enhance students' learning and the development of their competences.
\end{abstract}

Keywords: formative assessment, humour, student development, learning experience, differentiated classrooms 


\section{Introduction}

A considerable amount of literature has been published on the impact of formative assessment on student learning. There is a general consensus that students' learning experience and competences are enhanced with the increased use of formative assessment, as it leads to higher quality learning. Existing literature (Natriello, 1987; William and Bartholomew, 2004; Dunn and Mulvenon, 2009; Hill, 2011) provides ample evidence indicating that there is a need for educators to take time to develop innovative and well-defined formative assessment that will successfully support the academic needs of a diverse set of students in differentiated classrooms.

Slute (2008, p. 154) defines formative assessment as information communicated to the learner that is intended to modify his or her thinking or behaviour for the purpose of improving learning. Despite its importance, many universities still lay particular emphasis on externally-set tests and examinations, though this trend is slowly changing. Formative assessment is important as it not only tests students' cognitive abilities and graduate attributes, but more importantly, it is also part of the feedback process in which students are able to evaluate their response and understanding with the feedback they receive, and make necessary adjustments. Yorke (2003) aptly states that '....Formative assessment is critically important for student learning. Without informative feedback on what they do, students will have relatively little by which to chart their development.'

Aside from formative assessment, humour is generally believed to have a positive impact on students' learning experience and is often advised as a best practice by effective educators. An effective educator is one who is able to impart knowledge, to inspire and to transform lives. Henry Adams's wise words come to mind: 'A teacher affects eternity: he can never tell where his influence stops.' Teaching can only be effective if learning takes place. While being knowledgeable is important, it is not perceived to have the greatest impact on students' learning experience. An educator who uses humour and is perceived as humane is one who breaks down any imagined barriers and allows students access to the educator's knowledge, experience and life skills. Humour is the most genuine and universal speech act within human discourse, and it is employed as a technique in creative pedagogy, emphasizing the skill and art of the educators (Bradshaw \& Lowenstein, 2011; Meeus \& Mahieu, 2009; Martin, 2007; Ulloth, 2002). 


\section{Research Problem}

A substantial body of literature has been published on the scholarship of teaching and learning. With the turn of the century, there has been increasing demand for higher education to effectively develop students in terms of their knowledge and comprehension, as well as in building their graduate attributes. What strategies do educators need to implement in order to encourage learning and soft skills development in their students? How can we ensure we are addressing students' needs instead of simply teaching them what we think they need? The literature on learning provides a wide array of strategies that are effective, with formative assessment being one of the main strategies employed. Black and William (1998); Yorke (2003); Hudson and Bristow (2006); and Nicol and McFarlane-Dick (2006) in their respective studies revealed that formative assessment significantly enhances learning and helps develop lifelong learning skills by assisting students to self-regulate their learning. Rushton (2005) believes that feedback from formative assessment can improve learning, as students become more motivated to learn when they realize that there is a gap between what they thought they knew and what they actually know.

Fisher and Frey (2007) acknowledge that formative assessments are ongoing in nature and aid students via the feedback received, and help inform teacher instruction. Formative assessments help educators to differentiate instruction and therefore improve students' learning and development. Stiggins (2007) uses the concept of "assessment of learning" to describe formative assessments, as educators assess their students' learning to ascertain that these students are meeting the required standards set by the state, district, or institution of higher education. Formative assessment is extremely important especially in differentiated classrooms, where students of varying levels of readiness sit side by side. In a nutshell, formative assessment is an effective tool that can be used to identify gaps in knowledge, diagnose specific misunderstandings, foster self-study and clarify desired outcomes. Formative assessment that is well-designed augurs well with the core of Dewey's educational philosophy (1933), in which education must lead to personal growth, contribute to humane conditions and engage citizens in association with one another.

Aside from formative assessment, another important tool used by effective educators to encourage learning is the use of humour in lessons. Ziv (1979) provides a theoretical explanation for the humour-learning relationship based on the theory of attention-gaining and holding power of humour. Smith (2007) reveals that boredom may be the largest pedagogical obstacle to teaching and learning. Educators are responsible for stimulating students' interest in lessons in 
differentiated classrooms. Humour is believed to be one of the most effective ways of igniting students' enthusiasm.

Numerous studies (Berk, 2003; Chauvet and Hofmeyer, 2006; Baid and Lambert, 2009; Englert, 2010; Golchi and Jamali, 2011; Zhao, Kong and Wang, 2012) have shown the positive impact humour has on students' learning experience as it can create a conducive, non-threatening learning environment, increasing student-instructor interaction, enhancing lectures through variety, enhancing cognitive stimulation, decreasing anxiety, motivating students to learn and enjoy greater satisfaction with learning; enhancing creativity and divergent thinking, having a better ability to cope with stress, and providing enjoyment and laughter.

Deneire (1995, p. 285) said that ' $[\mathrm{h}]$ umor has been [...] shown to have a positive effect on the learning environment, to initiate, maintain, and enhance learner interest, and to facilitate retention.' This was iterated by Martin (2007), who explained that humour improved the learning experience, as it increased the satisfaction of learning and motivated students to think.

Based on the above literature review, it is evident that students' learning experience and development are determined by an array of factors, and it is therefore imperative to continuously embark on research to elicit meaningful evidence on the various factors affecting students' learning experience as well as the development of their graduate attributes. This will enable higher education institutions to implement comprehensive assessment strategies that will enhance students' learning experience and equip them with the necessary skills for future use.

\section{Research Focus}

The present study focuses on the impact of formative assessment and humour in class on students' learning experience and skill development. Formative assessment has its roots in Dewey's theory of experience and primacy of education. The study was conducted to add value to the existing literature on the impact of formative assessment and humour on learning experience and student development among business undergraduates. The study aims to provide a much needed insight into students' perception of the key factors that enhance their learning experience and graduate attributes.

The following four hypotheses were tested in this study:

H1: Formative assessment is perceived to have a significant positive influence on learning experience. 
$\mathrm{H} 2$ : Formative assessment is perceived to have a significant positive influence on student development.

H3: Humour is perceived to have a significant positive influence on learning experience.

H4: Humour is perceived to have a significant positive influence on student development.

\section{Research Methodology}

\section{Research General Background}

The presented study involved an investigation into the effects of the use of formative assessment in the form of applied academic writing and poster presentations, and the use of humour in class, to investigate the impact they have on students' learning experience and the development of core competences.

Figure 1 illustrates the conceptual framework employed in this study. The regressors represent the explanatory variables that are believed to have an impact on students' learning experience and the development of graduate attributes. The explanatory variables comprise formative assessment and humour.

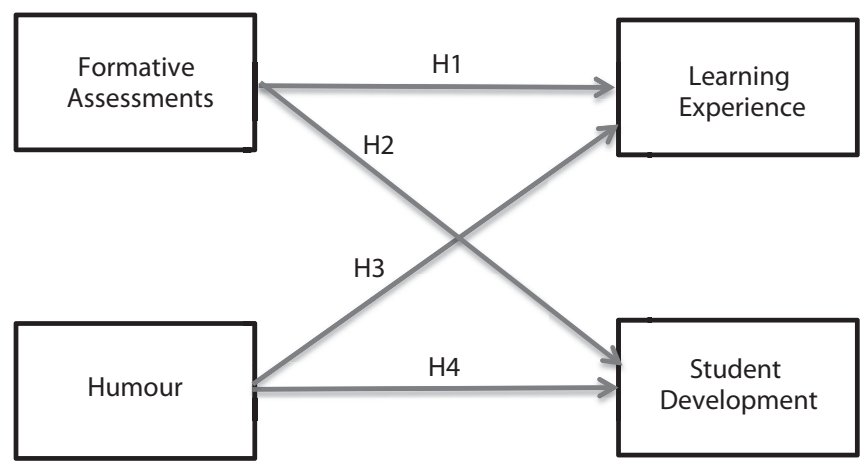

Figure 1. Conceptual Framework 


\section{Research Sample}

236 respondents were selected using simple random sampling. The respondents were undergraduate students of a private university in Malaysia.

\section{Instrument and Procedures}

The data was collected based on a specially-designed online survey of undergraduate business students to elicit information with regards to their perception of the factors that enhanced their learning experience and developed their graduate attributes. The questionnaire utilizes a 1-5 Likert-scale format to measure the extent to which the students perceived the impact that formative assessment and humour had on their learning experience and developing their graduate attributes.

\section{Data Analysis}

Partial Least Squares-Structural Equation Modeling (PLS-SEM) method using SmartPLS 2.0 was employed to test the hypotheses of this study. PLS-SEM has the advantage of having the ability to deal with formative constructs, small sample sizes and is suitable for assessing relatively new measurement models. Tenenhaus et al. (2005), and Henseler, Wilson, and Westberg (2011) found that empirical models with both reflective and formative constructs can be analysed with the use of PLS-SEM. The sample size in our study was considered sufficient to achieve the desired statistical power (Hair, Hult, Ringle \& Sarstedt, 2013). This study employed the PLS algorithm, in which the path coefficients were estimated, while the hypotheses were tested by means of bootstrapping with 1000 samples, as in Becker, et al. (2012).

\section{Research Results}

\section{Respondents' Demographics}

There were 236 respondents, of whom 33\% were males and $67 \%$ were females. The respondents were diverse in ethnicity, with the majority being Chinese (57\%), followed by Malays (24\%) and Indians (8\%) and a handful of other ethnic groups. 


\section{Measurement Model}

Arbuckle $(2005,113$, p.89) claims that the portion of the model that specifies how the observed variables depend on the unobserved, composite, or latent variables' is also known as the measurement model. Each of the constructs comprising Assessments, Humour, Learning Experience and Student Development was analysed in the measurement model. Pedhazur and Schmelkin (1991) stated that the fundamental purpose of employing the measurement model was to assess the construct and convergent validity of the constructs being studied. The construct validity can be established by undertaking convergent and discriminant validity, as revealed by Hair et al. (2010).

The convergent validity was assessed to ensure that the items of each scale measured the same construct. The composite reliability, the Average Variance Extracted (AVE), the item factor loadings (Fornell \& Larcker, 1981) and the significance of the outer loadings (Gefen and Straub, 2005) were examined for this purpose. Since the AVE for each construct is greater than 0.5 , while the composite reliability is greater than 0.7, and the t-statistic of the outer loading is greater than 1.96 (Gefen and Straub, 2005), convergent validity exists.

Fornell \& Larcker (1981) say that the Cronbach alpha and composite reliability are used to assess the internal consistency of the scales used to measure each construct. Since the values of the Cronbach alpha for all constructs are over 0.7, this reflects the existence of internal consistency as in Nunnally (1978). As shown in Table 1, the Cronbach alpha values for Assessment, Humour, Learning Experience and Student Development are all above the 0.7 recommended cut-off.

Yet another measure of internal consistency is the composite reliability, which according to Agarwal \& Karahanna (2000) and Staples and Seddon, (2004) is considered acceptable when it is 0.7 or above. As shown in Table 1, the composite reliability values for Assessment, Humour, Learning Experience and Student Development are all above the 0.7 recommended cut-off.

Table 1 also shows that our model revealed predictive power (R-square), as assessment and humour explained $71.4 \%$ and $53.2 \%$ of the variance in learning experience and student development respectively.

Table 1. Measures of Internal Consistency

\begin{tabular}{|c|c|c|c|c|c|}
\hline Scale & $\begin{array}{l}\text { No. of } \\
\text { Items }\end{array}$ & $\begin{array}{c}\text { Cronbach's } \\
\text { Alpha }\end{array}$ & $\begin{array}{l}\text { Composite } \\
\text { Reliability }\end{array}$ & $\mathrm{R} 2$ & AVE \\
\hline Assessment (A) & 7 & 0.881 & 0.907 & & 0.588 \\
\hline Humour $(\mathrm{H})$ & 8 & 0.900 & 0.919 & & 0.588 \\
\hline
\end{tabular}




\begin{tabular}{llllll}
\hline \multicolumn{1}{c}{ Scale } & $\begin{array}{c}\text { No. of } \\
\text { Items }\end{array}$ & $\begin{array}{c}\text { Cronbach's } \\
\text { Alpha }\end{array}$ & $\begin{array}{c}\text { Composite } \\
\text { Reliability }\end{array}$ & R2 & AVE \\
\hline Learning Experience (LE) & 7 & 0.883 & 0.910 & 0.714 & 0.595 \\
\hline $\begin{array}{l}\text { Student Development } \\
\text { (SD) }\end{array}$ & 5 & 0.834 & 0.884 & 0.532 & 0.609 \\
\hline
\end{tabular}

a: Composite Reliability $(\mathrm{CR})=(\Sigma \text { factor loading })^{2} /\left\{(\Sigma \text { factor loading })^{2}\right)+\Sigma$ (variance of error $\left.)\right\}$

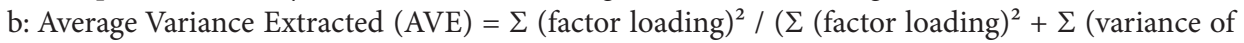
error)\}

To confirm the construct validity of the outer model, there is a need to establish the discriminant validity, which is the degree to which the items of a particular scale measure only the construct they should measure (Whitley, 2002). We assessed discriminant validity for Assessment, Humour, Learning Experience and Student Development and the results are shown in Table 2.

Gefen and Straub (2005) reveal that each square root of the AVE should be larger than its correlation with the other constructs in order for a construct to demonstrate discriminant validity. As shown in Table 2, there is evidence that the four constructs have discriminant validity. Therefore, it can be safely stated that the findings of the hypotheses (Table 3 ) are valid and reliable.

Table 2. Discriminant Validity

\begin{tabular}{lcccc}
\hline & Assessment & Humour & $\begin{array}{c}\text { Learning } \\
\text { Experience }\end{array}$ & $\begin{array}{c}\text { Student } \\
\text { Development }\end{array}$ \\
\hline Assessment & $\mathbf{0 . 7 6 7}$ & & & \\
\hline Humour & 0.559 & $\mathbf{0 . 7 6 7}$ & & \\
\hline Learning Experience & 0.728 & 0.603 & $\mathbf{0 . 7 7 1}$ & \\
\hline Student Development & 0.677 & 0.602 & 0.688 & $\mathbf{0 . 7 8 0}$ \\
\hline
\end{tabular}

Table 3 presents the results of the analysis of the structural model using the PLS method and bootstrapping technique with 1000 samples.

Table 3. Path Estimates

\begin{tabular}{llllll}
\hline Hypotheses & Beta & S.Error & t-statistic & Decision \\
\hline H1 & $\begin{array}{l}\text { Assessment -> } \\
\text { Learning } \\
\text { Experience }\end{array}$ & 0.714 & 0.066 & 10.780 & confirmed \\
& & & & \\
\hline
\end{tabular}


Vinitha Guptan, Ratneswary Rasiah

\begin{tabular}{llllll}
\hline Hypotheses & Beta & S.Error & t-statistic & Decision \\
\hline H2 & $\begin{array}{l}\text { Assessment }-> \\
\text { Student } \\
\text { Development }\end{array}$ & 0.495 & 0.122 & 4.075 & confirmed \\
\hline H1 & $\begin{array}{l}\text { Humour.....->. } \\
\text { Learning } \\
\text { Experience }\end{array}$ & 0.204 & 0.082 & 2.482 & confirmed \\
\hline $\mathrm{H} 2$ & $\begin{array}{l}\text { Humour.....->. } \\
\text { Student } \\
\text { Development }\end{array}$ & 0.326 & 0.122 & 2.660 & confirmed \\
& & & & \\
\hline
\end{tabular}

As shown, assessment has a significantly positive effect on learning experience (standardized estimate $=0.714 \mathrm{p}<0.05$ ). On the other hand, assessment also has a significant and positive impact on student development (standardized estimate $=0.495 \mathrm{p}<0.05$ ). As far as humour is concerned, it also has a significantly positive impact on both learning experience (standardized estimate $=0.204 \mathrm{p}<0.05$ ) and student development (standardized estimate $=0.326 \mathrm{p}<0.05$ ).

\section{Discussion}

The findings of the present study reveal that assessment has a significantly positive impact on learning experience, hence supporting the first hypothesis. The results also reveal that students' competences of graduate capabilities are enhanced after completing their assessment, thereby supporting hypothesis 2. Humour, on the other hand, also plays a significantly positive role in enhancing students' learning experience and their competences or graduate capabilities, hence supporting hypotheses 3 and 4 .

The empirical evidence of this study shows that the students' learning experience is significantly and positively impacted on by formative assessment and humour. These findings concur with those found by Englert (2010); Golchi and Jamali (2011); Zhao, Kong and Wang (2012) and Rasiah (2015) for assessment; and Deneire (1995); Martin (2007) and Bradshaw \& Lowenstein (2011) for humour. Our results show that formative assessment has a greater impact on students' learning experience as compared to humour, showcasing the importance of designing good assessment and effective and timely feedback to ensure deep and meaningful learning takes place, as supported by the findings of Duncan (2007); and Nicol and Draper (2008), among others. 
In terms of student development, the results also reveal that formative assessment and humour are significant contributors to developing student competences, in terms of enhancing their graduate attributes, as supported by the findings of Golchi and Jamali, 2011; Zhao, Kong and Wang, 2012 and Rasiah (2015), among others.

This study has some limitations, especially with respect to the questionnaire developed, which has room for further improvement. Despite that, the findings certainly provide an insight into students' perceptions of the impact of formative assessment and humour on their learning and the impact that this has on the competences they gained or enhanced along the way.

\section{Conclusions}

The findings demonstrate the effectiveness of employing formative assessment and humour in the classroom to enhance learning experience and develop graduate attributes. The policy implication of this study is that higher education institutions put a heavier emphasis on ensuring that students are tested with well-designed formative assessment to promote wider, deeper and more sustained learning, by keeping the focus on teaching and learning, aligning summative and formative assessment approaches, investing in training and support for formative assessment, encouraging innovation in assessment and building stronger bridges between research, policy and practice. As far as humour is concerned, it is recommended that educators consider the use of humour as a mechanism for reducing stress and tension and creating a more positive learning environment, and ample training be provided to enhance educators' ability to motivate, inspire and engage students in the learning process.

\section{References}

Agarwal, R. and Karahanna, E. (2000). Time Flies When you're Having Fun: Cognitive Absorption and Beliefs about Information Technology Usage, MIS Quarterly, 24(4), 665-694.

Arbuckle, J.L., (2005). Amos 6.0 User's Guide. Chicago, IL: SPSS Inc.

Becker, J.Mz., Klein, K., Wetzels, M. (2012). Hierarchical Latent Variable Models in PLSSEM: Guidelines for Using Reflective Formative Type Models. Long Range Planning, $45,359-394$.

Berk, R.A. (2003). Professors are from Mars, Students are from Snickers: How to Write and 
Deliver Humor in the Classroom and in Professional Presentations. Sterling, Virginia: Stylus Publishing.

Black, P. and William, D. (1998). Assessment and classroom learning. Assessment in Education, 5(1), 7-74.

Bradshaw, M.J., and Lowenstein, A.J. (2011). Innovative teaching strategies in nursing and related health professions ( $5^{\text {th }}$ ed.). Sudbury, MA: Jones and Bartlett.

Dewey, J. (1933). How We Think: A Restatement of Reflective Thinking to the Educative Process. Boston: D.C. Heath. (Original work published in 1910).

Deneire, Marc (1995): "Humor and foreign language teaching". In: Humor 8(3), pp. 285-298.

Dormann, C., and Biddle, R. (2006). Humour in game-based learning. Learning, Media, and Technology, 31(4), 411-424.

Duncan, N. (2007). Feed-forward: improving students' use of tutor comments, Assessment \& Evaluation in Higher Education. 32 (3), 271-283.

Dunn, Karee E and Mulvenon, Sean W. (2009). A Critical Review of Research on Formative Assessments: The Limited Scientific Evidence of the Impact of Formative Assessments in Education. Practical Assessment Research \& Evaluation, 14(7).

Englert, L.M. (2010). Learning with laughter: Using humor in the nursing classroom. Nursing Education Perspectives, 31(1), 48-49.

Fisher, D., \& Frey, N. (2007). Checking for understanding: Formative assessments for your classroom. Alexandria, VA: Association for Supervision and Curriculum Development.

Fornell, C., Larcker, D.F., 1981. Evaluating structural equation models with unobservable variables and measurement error. Journal of Marketing Research, 18(1), 39-50.

Forsyth, D.R. (2003). The Professor's Guide to Teaching: Psychological Principles and Practices. Washington, DC: American Psychological Association.

Gefen, D., and Straub, D.W. (2005). A Practical Guide to Factorial Validity Using PLSGraph: Tutorial and Annotated Example. Communications of the Association for Information Systems, 16(5), 91-109.

Golchi, M.M., \& Jamali, F. (2011). The effect of teacher's verbal humor on advanced EFL learners' classroom anxiety. European Journal of Social Sciences, 26, 185-192.

Hair, Joseph F., William C. Black, Barry J. Babin, and Rolph E. Anderson (2010), Multivariate Data Analysis, Englewood Cliffs, NJ: Prentice Hall.

Hair Jr, J.F., Hult, G.T.M., Ringle, C., \& Sarstedt, M. (2013). A primer on partial least squares structural equation modeling (PLS-SEM). Sage Publications.

Henseler. J.. Wilson. B., and Westberg, K. (2011). Managers' perceptions of the impact of sport sponsorship on brand equity: Which aspects of the sponsorship matter most? Sport Marketing Quarterly, 20, 7-21.

Hill, F.M. (2011) 'Getting traction': enablers and barriers to implementing Assessment for Learning in secondary schools. Assessment in Education: Principles, Policy and Practice, 18(4), 347-364.

Hudson, J.N. and Bristow, D.R. (2006). Formative assessment can be fun as well as educational. The American Physiological Society, 30, 33-37.

Jenkins, J.O. (2010). A multi-faceted formative assessment approach: better recognising 
the learning needs of students. Assessment \& Evaluation in Higher Education, 35(5), 565-576.

Martin, R.A. (2007). The psychology of humor: An integrative approach. San Diego, CA: Elsevier.

Meeus, W. and Mahieu, P. (2009). You can see the funny side, can't you? Pupil humour with the teacher as target. Educational Studies, 35(5), 553-560.

Natriello, G. (1987) The impact of evaluation processes on students, Educational Psychologist, 22(2), 155-175.

Nichol, D.J. and Macfarlane-Dick, D. (2006). Formative assessment and self-regulated learning: A model and seven principles of good feedback practice. Studies in Higher Education, 31(2), 199-218.

Nicol, D. \& Draper, S. (2008). Redesigning written feedback to students when class sizes are large. Paper presented at the Improving University Teachers Conference, July, Glasgow. Nunnally, J.C. (1978). Psychometric theory (2nd ed.). New York: McGraw-Hill.

Pedhazur, E.J., and Schmelkin, L.P. (1991). Measurement, design, and analysis: An integrated approach. Hillsdale, NJ: Erlbaum.

Rasiah, R. (2015). The Impact of Holistic Education Approaches on First-Year Experience of Business Undergraduates: Promoting Interactive and Creative Learning Environments. Taylor's $7^{\text {th }}$ Teaching and Learning Conference Proceedings 2015, 311-321.

Rushton, A. (2005). Formative assessment: A key to deep learning? Medical Teacher, 27 (6), 509-513.

Shute, V. (2008). Focus on Formative Feedback. Review of Education. Research. 78 (1), 154-189.

Staples, D.S. and Seddon, P. (2004). Testing the technology-to-performance chain model, Journal of Organizational and End User Computing, 16(4), 17-26.

Stiggins, R. (2007). Assessments through the student's eyes. Educational Leadership, 64(8), 22-26.

Tenenhaus, M., Esposito Vinzi, V., Chatelin, Y., and Lauro, C. (2005). PLS path modeling. Computational Statistics and Data Analysis, 48, 159-205.

Ulloth, J.K. (2002). The benefits of humor in nursing education. Journal of Nursing Education, 41, 476-481.

Wiliam, D. \& Bartholomew, H. (2004) It's not which school but which set you're in that matters: the influence of ability-grouping practices on student progress in mathematics, British Educational Research Journal, 30(2), 279-293.

Yorke, M. (2003) Formative assessment in higher education: Moves towards theory and the enhancement of pedagogic practice. Higher Education, 45(4), 477-501.

Zhao, J., Kong, F., and Wang, Y. (2012). Self-esteem and humor style as mediators of the effects of shyness on loneliness among Chinese college students. Personality and Individual Differences, 52, 686-690.

Ziv, A. (1979). L'humor en education: Approche psychologique. Paris: Edition Social Francaises. 